\title{
ЕКОНОМІКА
}

Науковий вісник НЛТУ України
Scientific Bulletin of UNFU
https://nv.nltu.edu.ua
https://doi.org/10.36930/40310312
Article received 31.03.2021 p.
Article accepted 29.04.2021 p.
UDC 658.821

С. М. Пилипенко, Н. П. Банера, Л. О. Гелей

Львівський національний університет ім. Івана Франка, м. Львів, Украйна

\section{КЛАСИФІКАЦІЯ БУХГАЛТЕРСЬКОГО АУТСОРСИНГУ ТА ДОЦІЛЬНІСТЬ ЙОГО ЗАСТОСУВАННЯ В УКРАЇНI}

Виявлено проблему недостатнього рівня розвитку аутсорсингу в Україні, проте відзначено наявність значного потенціалу для забезпечення цього процесу. З'ясовано сутність та мету бухгалтерського аутсорсингу. Розглянуто основні засади організації бухгалтерського обліку на умовах аутсорсингу. Встановлено наявність істотних переваг користування послугами аутсорсингової компанії порівняно 3 веденням бухгалтерського обліку внутрішньою бухгалтерською службою підприємства. Наведено перелік послуг, що надаються аутсорсинговими компаніями. Узагальнено класифікацію бухгалтерського аутсорсингу за такими ознаками, як: тривалість надання, обсяг переданих ділянок обліку, спосіб співпраці між аутсорсинговою компанією та підприємством-замовником послуг, територіальне розміщення, обсяг виконаної аутсорсинговою компанією роботи. Охарактеризовано класифікацію процесів, явищ та характеристик, що пов'язані з бухгалтерським аутсорсингом. Виявлено необхідність ретельного обгрунтування доцільності аутсорсингу на етапі прийняття рішення про його застосування. Обгрунтовано доцільність використання бухгалтерського аутсорсингу для малих та середніх підприємств. Проаналізовано можливість розподілу облікових функцій між аутсорсинговою компанією та штатними бухгалтерами через спільний доступ до бухгалтерських програм для великих підприємств. Обгрунтовано доцільність застосування моделі розрахунку економічного ефекту від упровадження бухгалтерського аутсорсингу, наведено порядок його кількісного розрахунку та визначення альтернативного варіанта організації і ведення бухгалтерського обліку. Визначено вплив якісних методів оцінювання ефективності бухгалтерського аутсорсингу. Наведено чинники, які $є$ визначальними у прийнятті рішення щодо доцільності бухгалтерського аутсорсингу. Проаналізовано вибір підприємством повного або часткового аутсорсингу. Рекомендовано пошук і вибір аутсорсингової компанії здійснювати з урахуванням проведеного аналізу ринку. Визначено доцільність складання технічного завдання, де відображаються основні критерії відбору, та врахування стандартного чи розширеного варіанта ведення бухгалтерського аутсорсингу. Відзначено перспективи розвитку вітчизняного бухгалтерського аутсорсингу, які пов'язані з удосконаленням нормативно-правового регулювання цього процесу.

Ключові слова: бухгалтерський облік; бухгалтерський аутсорсинг; аутсорсер; види бухгалтерського аутсорсингу; доцільність здійснення бухгалтерського аутсорсингу.

\section{Вступ}

Розвиток аутсорсингу в Україні є відносно новим та недостатньо розвиненим видом діяльності, однак наявність значного потенціалу для його розвитку дає змогу 3'являтися на вітчизняному просторі щораз більшій кількості успішних аутсорсингових компаній. Доказом цьому слугує рейтинг найкращих світових постачальників послуг із аутсорсингу - Global Outsourcing 100, до списку якого з кожним роком входить дедалі більше українських компаній (у 2020 р. - 21 компанія). Запровадження аутсорсингу зможе істотно підвищити конкурентоспроможність вітчизняних підприємств.
Ведення бухгалтерського обліку в умовах аутсорсингу передбачає організацію та повне або часткове ведення бухгалтерського обліку підприємства, складання і подання його фінансової звітності аутсорсером - зовнішнім для підприємства виконавцем. При цьому метою бухгалтерського аутсорсингу є забезпечення задоволення інтересів замовника та виконавця на підставі оптимального поєднання правового та договірного регулювання цього процесу, що спричинено неспроможністю залучення висококваліфікованого штатного облікового персоналу внаслідок обмеженості фінансових ресурсів і масштабів діяльності підприємств.

Об'єкт дослідження - організація та ведення бух-

Інформація про авторів:

Пилипенко Соломія Миколаївна, канд. екон. наук, доцент, кафедра управління та експертизи товарів. Email: sol6ka@gmail.com; https://orcid.org/0000-0002-1145-5663

Банера Надія Петрівна, канд. екон. наук, доцент, кафедра управління та експертизи товарів. Email: nadiyabanera@ua.fm; https://orcid.org/0000-0002-6486-820X

Гелей Людмила Олегівна, канд. екон. наук, доцент, кафедра управління та експертизи товарів. Email: ludageley@i.ua; https://orcid.org/0000-0003-4564-5374

Цитування за ДСтУ: Пилипенко С. М., Банера Н. П., Гелей Л. О. Класифікація бухгалтерського аутсорсингу та доцільність його застосування в Україні. Науковий вісник НЛТУ України. 2021, т. 31, № 3. С. 80-84.

Citation APA: Pylypenko, S. M., Banera, N. P., \& Heley, L. O. (2021). Classification of accounting outsourcing and appropriateness of its application in Ukraine. Scientific Bulletin of UNFU, 31(3), 80-84. https://doi.org/10.36930/40310312 
галтерського обліку із застосуванням аутсорсингу.

Предмет дослідження - сукупність теоретичних, організаційних та методичних аспектів бухгалтерського аутсорсингу.

Мета роботи - обгрунтування науково-практичних підходів до класифікації бухгалтерського аутсорсингу в Україні та доцільності його здійснення, що дасть змогу обгрунтувати підходи до організації обліку в умовах його застосування, а також допоможе підприємству оптимізувати витрати та сконцентрувати увагу на головній місії.

Для досягнення зазначеної мети визначено такі ocновні завдання дослідження: розглянути основні засади організації бухгалтерського обліку на умовах аутсорсингу; встановити наявність переваг при користуванні послугами аутсорсингової компанії; визначити перелік послуг, що надаються бухгалтерами-аутсорсерами; узагальнити класифікацію бухгалтерського аутсорсингу та процесів, явищ і характеристик, що пов'язані з бухгалтерським аутсорсингом; обгрунтувати доцільність аутсорсингу на етапі прийняття рішення про його застосування для малих, середніх та великих підприємств та доцільність застосування моделі розрахунку економічного ефекту від упровадження бухгалтерського аутсорсингу; окреслити перспективи розвитку вітчизняного бухгалтерського аутсорсингу.

Наукова новизна отриманих результатів досліджен$н я$ - вперше узагальнено та систематизовано класифікацію бухгалтерського аутсорсингу, вперше введено класифікаційну ознаку бухгалтерського аутсорсингу - за обсягом виконаної аутсорсинговою компанією роботи, обгрунтовано доцільність здійснення бухгалтерського аутсорсингу в Україні.

Практична значущість результатів дослідження виконані узагальнення та систематизація видів бухгалтерського аутсорсингу дає змогу обгрунтувати підходи до організації обліку в умовах його застосування, а обгрунтування доцільності здійснення бухгалтерського аутсорсингу допомагає підприємству оптимізувати витрати та сконцентрувати увагу на головній місії.

Аналіз останніх досліджень та публікацій. Вагомий внесок у вивчення деяких аспектів бухгалтерського аутсорсингу здійснили такі вчені та науковці: О. I. Волот [8], Т. В. Давидюк [1], Г. С. Кесарчук [2], Г. І. Ляхович [3, 4, 5], О. В. Назаренко [6], Л. С. Скакун [7] та ін.

Делегування бухгалтерських функцій аутсорсинговій компанії дещо стримується через наявність недоліків бухгалтерського аутсорсингу, що певною мірою гальмує доцільність запровадження та розвиток аутсорсингу в Україні. Однак, передаючи аутсорсинговій компанії ведення бухгалтерського обліку, підприємство отримує багато переваг. Такі переваги і недоліки досліджено у праці О. В. Назаренко [6].

Поділ бухгалтерського аутсорсингу за окремими класифікаційними ознаками наведено у працях О. I. Волот [8], Г. С. Кесарчук [1] та Г. І. Ляхович [3]. Давидюк Т. В. обгрунтувала критерії вибору аутсорсера на ринку аутсорсингових послуг 3 погляду їх якості та ефективності - орієнтація на кількісних методах оцінювання, таких як економічний ефект, та якісних методах оцінювання ефективності бухгалтерського аутсорсингу, що виражено в алгоритмі відбору аутсорсингової компанії [1].
На необхідності оцінення ефективності й доцільності бухгалтерського аутсорсингу шляхом аналізування наявних підходів до методики їі проведення наголошує і Г. І. Ляхович $[4,5]$. Автор наявні методи такого оцінювання умовно об'єднує у схематичні (матричні) та розрахунково-економічні. Використання матричного методу для оцінення ефективності використання аутсорсингу докладно охарактеризовано у дисертації Л. С. Скакун [7].

Проте перелік проблемних питань у цьому напрямку ще не вичерпано й вимагає подальшого теоретичного обгрунтування питання класифікації та доцільності здійснення бухгалтерського обліку на умовах аутсорсингу як важливого інноваційного інструмента досягнення економічних переваг у діяльності підприємств.

Матеріали та методи дослідження. Теоретичним і методологічним підгрунтям дослідження є фундаментальні надбання сучасної економічної науки, доробок вітчизняних вчених щодо окремих аспектів організації і ведення бухгалтерського обліку на умовах аутсорсингу. Дослідження виконували на підставі застосування загальнонаукових методів і прийомів: узагальнення та систематизації - для класифікації бухгалтерського аутсорсингу; аналізу та синтезу - для оцінювання доцільності вибору аутсорсингу як форми організації бухгалтерського обліку, експертних оцінок - під час формування системи чинників, що визначають вибір аутсорсингової компанії. Основним статистичним методом була описова статистика - дані рейтингу найкращих світових постачальників послуг із аутсорсингу - Global Outsourcing 100.

\section{Результати дослідження та їх обговорення}

Термін "бухгалтерський аутсорсинг" має багато синонімів в українській мові - "аутсорсинг бухгалтерського обслуговування", "аутсорсинг бухгалтерських послуг", "бухгалтерський облік на умовах аутсорсингу", однак у будь-якому випадку означає передачу аутсорсинговій компанії функцій з організації та ведення бухгалтерського обліку підприємства. Вважаємо за доцільне вживати термін "бухгалтерський аутсорсинг", оскільки саме таке словосполучення без завуальованості інтерпретує це поняття. Аутсорсингова компанія, як цілісний функціональний підрозділ, що є організаційно і юридично самостійним, залучається в робочі бізнеспроцеси підприємства, яке замовило бухгалтерський аутсорсинг, на підставі укладеного між ними договору про надання бухгалтерських послуг на умовах аутсорсингу [7].

Сьогодні українські підприємства, щоб скоротити витрати на утримання внутрішньої бухгалтерської служби та отримати якісніше бухгалтерське обслуговування, дедалі частіше звертаються до аутсорсингових компаній. Висока якість послуг, що надаються аутсорсинговими компаніями, зумовлена тим, що працівники компанії - аутсорсери для якісного виконання покладених на них завдань постійно підвищують свою кваліфікацію, що дає їм змогу не тільки достовірно відображати факти господарської діяльності підприємства, але й знаходити резерви раціонального використання наявного у підприємства майна. Отже, підприємства можуть доручити виконання складних завдань більш компетентним фахівцям. 
Загалом аутсорсингові компанії можуть бути залучені до розроблення облікової політики, відновлення та ведення бухгалтерського обліку, складання фінансової звітності, оптимізації податкових платежів та інших відрахувань чи повністю взяти на себе весь бухгалтерський облік - обслуговування "під ключ", що власне $\epsilon$ найпопулярнішою послугою бухгалтерського аутсорсингу та містить ведення бухгалтерського та податкового обліку, здачу звітності в усі органи контролю, роботу 3 клієнт-банком, контроль сплати всіх податкових зобов'язань, супровід перевірок, спілкування 3 органами контролю, архівування та зберігання документів тощо. Обсяг послуг, які надаються аутсорсинговою компанією, залежать від фінансової спроможності замовника.

Недосконалість законодавчого регулювання та нестача наукової літератури не дає змоги сформувати чітку класифікацію бухгалтерського аутсорсингу. Поділ бухгалтерського аутсорсингу за окремими класифікаційними ознаками наведено у науковій літературі $[3,8]$, однак вважаємо за доцільне здійснити це за класифікаційними ознаками, наведеними на рисунку.

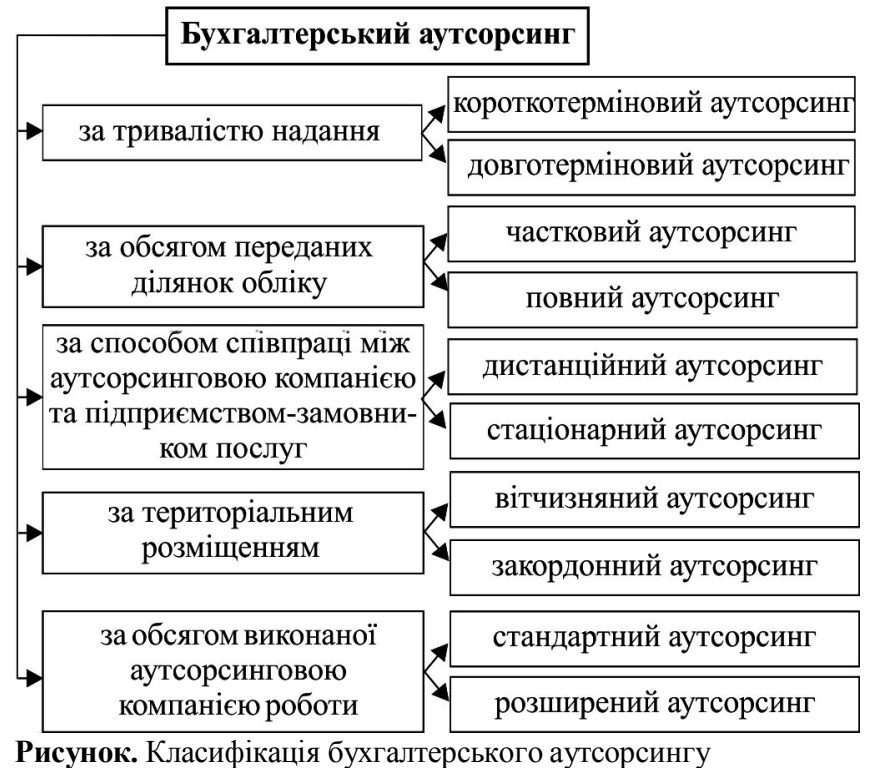

Бухгалтерський аутсорсинг за тривалістю надання поділяють на короткотерміновий аутсорсинг, за якого період користування послугами аутсорсингової компанії становить менше одного року, і довготерміновий аутсорсинг, за якого період користування послугами аутсорсингової компанії - більше одного року.

За обсягом переданих на аутсорсинг ділянок бухгалтерського обліку він буває частковий - ведення аутсорсинговою компанією однієї ділянки обліку, що підійде для великих фірм, де є штатний бухгалтер, а бухгалтераутсорсер може виконувати тільки деякі неосновні функції, і повний - ведення всього обліку підприємства, до якого вдаються невеликі підприємства, які не можуть дозволити собі штатного бухгалтера.

Різновидом цієї класифікації є варіант взаємодії аутсорсингової компанії із замовником, котрий додатково передбачає існування моделей "зовнішній контролер" та "абонентське обслуговування". "Зовнішній контролер" передбачає, що аутсорсер перевіряє бухгалтерську документацію, аналізує роботу підприємства та дає висновок про те, як поліпшити його діяльність. У разі використання моделі "абонентське обслуговування" аутсорсер виступає консультантом, в основному, з питань нововведень. Допускаються і змішані варіанти співпраці аутсорсингової компанії та підприємства [2].

Класифікація бухгалтерського аутсорсингу за способом співпраці між аутсорсинговою компанією та підприємством-замовником послуг передбачає дистанційний (спілкування за допомогою електронної пошти, телефонного зв'язку, соціальних мереж тощо) та стаціонарний (спілкування переважно особисто, але і за допомогою засобів комунікації) бухгалтерський аутсорсинг. Територіальне розташування аутсорсингової компанії визначає функціонування вітчизняного аутсорсингу, який існує в межах держави, в якій знаходиться підприємство-замовник послуг, та закордонного аутсорсингу, який розміщується за межами країни-замовника аутсорсингових послуг.

За обсягом виконаної аутсорсинговою компанією роботи розрізняють стандартний і розширений аутсорсинг. Стандартний варіант передбачає ведення бухгалтерського обліку та складання звітності на підставі наданих клієнтом первинних документів. При цьому бухгалтер аутсорсингової компанії не аналізує достовірність зазначеної у цих документах інформації. Для розширеного варіанта ведення бухгалтерського обліку характерний повний супровід клієнта: оформлення первинних документів, складання та подання звітності, ведення бухгалтерського та податкового обліку, оформлення внутрішніх документів. У разі вибору цього виду аутсорсингова компанія попередньо ознайомлюється з наданими їй документами.

Окрім класифікації власне бухгалтерського аутсорсингу класифікують і процеси, явища, характеристики, що з ним пов'язані. Зокрема за видами делегованих на аутсорсинг функцій їх поділяють на бухгалтерські, аудиторські, юридичні та комбіновані; за ймовірністю здійснення помилок - низьку, достатню, високу; за врахуванням стандартів складання фінансової звітності за НП(С)БО, МСБО, МСФЗ; за цілями застосування повне ведення обліку, виявлення невідповідностей, підвищення рівня штатного персоналу, інше; за спрямуванням на центр відповідальності - пов'язані з виробничими потребами, пов'язані 3 доходами і витратами, пов'язані з управлінською стратегією, інше; за галузями здійснення бухгалтерського обліку - виробництво, послуги, інше; за частотою користування послугами - одноразові, кількаразові, багаторазові; за обсягом охоплення послуг - системні, вибіркові $[6,8]$.

На етапі прийняття рішення про застосування аутсорсингу потрібно мати ретельне обгрунтування його доцільності [4]. Найвигіднішим аутсорсинг є для малих і середніх підприємств. Вони можуть передати всі ділянки бухгалтерського обліку аутсорсинговій компанії, оскільки кількість господарських операцій $є$ незначною. Бухгалтер аутсорсингової компанії зазвичай володіє достатньою компетенцією для того, щоб кваліфіковано та якісно вести облік діяльності цих суб'єктів господарювання.

Щодо великих підприємств, де значний документообіг та реалізація продукції (товарів, робіт, послуг) відбувається щодня, необхідний штатний бухгалтер, який вестиме облік на виробничій ділянці. Усі інші функції такі підприємства можуть довірити аутсорсинговій компанії. Така взаємодія штатного бухгалтера та бухгалтера-аутсорсера можлива через спільний доступ до бухгалтерських програм. 
Сьогодні існує багато різних моделей і методик обгрунтування доцільності застосування аутсорсингу загалом, що пов'язано з різними підходами до оцінювання ефективності та різноманіттям видів аутсорсингу. Проте найефективнішою $є$ оцінка економічної ефективності або розрахунок економічного ефекту від упровадження бухгалтерського аутсорсингу, що найбільшою мірою випливає 3 його переваги - "низька вартість послуги" та полягає в економії витрат при веденні обліку аутсорсинговою компанією порівняно із веденням обліку власною бухгалтерською службою. Це дає змогу кількісно оцінити ефективність бухгалтерського аутсорсингу. Якщо співвідношення обсягу витрат на утримання бухгалтерської служби до обсягу вартості послуг аутсорсингової компанії більше одиниці, то вибір падає на користь послуг аутсорсера. Якщо ж це співвідношення менше одиниці, то підприємству варто зберегти внутрішню бухгалтерську службу $[1,5]$.

Поряд із цим для обгрунтування доцільності застосування аутсорсингу використовують підхід до оцінювання ефективності, який передбачає співвідношення між ефектом і понесеними витратами, що випливає із класичного трактування економічного ефекту.

Окрім кількісних, використовують і якісні методи оцінювання ефективності бухгалтерського аутсорсингу: ступінь досягнення цілей і завдань, поставлених перед системою обліку; рівень інформаційного ризику; налагодження безперервних інформаційних потоків для прийняття управлінських рішень; достовірність звітної документації; своєчасне надання звітної документації; зниження кількості бухгалтерських помилок; відсутність штрафних санкцій $[5,7]$.

Приймаючи рішення про доцільність бухгалтерського аутсорсингу, необхідно з'ясувати, які саме ділянки бухгалтерського обліку потрібно передати на аутсорсинг. При цьому треба врахувати низку чинників, зокрема: розміри підприємства та кількість бухгалтерських операцій; потреби управлінського персоналу в оперативній інформації, наявність інформації, що становить комерційну таємницю тощо.

Передача на аутсорсинг повністю усіх операцій з ведення бухгалтерського обліку доцільна для таких груп підприємств, як мікропідприємства, обсяг операцій у яких малий, та малі і середні підприємства, діяльність яких є відносно стабільною, а завантаження бухгалтерів часто нижче від нормативного значення. Такі групи підприємств досить часто або неповною мірою завантажують облікових працівників, або перевантажують обов'язками, що призводить до надмірних витрат на оплату праці, а це, своєю чергою, не відповідає виконуваним обов'язкам. Тому для таких підприємств вигідним $\epsilon$ повний бухгалтерський аутсорсинг.

Великим підприємствам складно реалізувати бухгалтерський аутсорсинг, оскільки знижується оперативність інформації. Здебільшого вони обирають частковий аутсорсинг, що стосується певних облікових ділянок, і немає необхідності в оперативній інформації. Не менш важливим у виборі варіанта ведення бухгалтерського обліку є врахування того факту, що деякі операції підприємства пов'язані з комерційною таємницею, тому задля уникнення розголошення їх доцільно залишити для внутрішньої бухгалтерської служби.

На етапі пошуку і вибору сумлінної аутсорсингової компанії необхідно проаналізувати фірми, які $є$ на ринку, особливу увагу звернувши на такі чинники, як репу- тація, надійність, стабільний розвиток, досвід успішно реалізованих проектів, зокрема у тій самій сфері діяльності, наявність позитивних оцінок з боку замовників тощо [5]. Доцільно попередньо скласти технічне завдання, де будуть відображені основні критерії відбору кількість співробітників, їх кваліфікація, тимчасові межі виконання робіт, порядок і форма оплати, необхідний вид звітності тощо.

Також принциповим є можливість аутсорсингової компанії швидко підлаштуватися під особливості та специфіку, зміну діяльності підприємства. Аутсорсингова компанія повинна, за потреби, мати змогу надати додатковий сервіс або розширити наявний. Професійний рівень працівників такої фірми має бути на досить високому рівні, підтвердженням їх компетентності $\epsilon$ сертифікати та періодичне проходження атестацій.

Важливим у виборі аутсорсингової компанії є врахування варіанта ведення бухгалтерського аутсорсингу стандартного чи розширеного. Перевагами стандартного варіанта ведення обліку вважають низьку ціну, і для підприємств, у яких обсяги господарської діяльності незначні, такий аутсорсинг є доречним. Однак існує ризик виявлення розбіжностей під час проведення податкових перевірок та збільшення затрат праці аутсорсера i, відповідно, собівартості його послуг у разі несвоєчасного надання документів клієнтом, їх некоректного оформлення тощо. Якщо підприємство вибирає розширений вид, аутсорсингова компанія попередньо ознайомлюється 3 наданими їй документами. Перевагою такого варіанта ведення обліку є можливість істотного підвищення ефективності ведення бухгалтерського обліку.

Отже, тенденції розвитку вітчизняного ринку доводять, що бухгалтерський аутсорсинг стрімко розвивається в Україні та поступово стає звичайною практикою для підприємств. 3 кожним роком кількість аутсорсингових компаній в Україні зростає, що забезпечується стабільністю попиту і вказує на потребу й перспективи цього виду послуг. Незважаючи на те, що переважна кількість користувачів, що застосовують аутсорсинг, це підприємства малого бізнесу, зацікавленість в аутсорсерах сьогодні стрімко зростає і серед великого та середнього бізнесу.

Аналіз всіх проблемних питань щодо доцільності застосування бухгалтерського аутсорсингу в Україні дає змогу окреслити перспективи його розвитку, які, на наш розсуд, потрібно вирішувати на загальнодержавному рівні та пов'язувати з необхідністю прийняття відповідних нормативних документів. Нормативно-правове регулювання бухгалтерського аутсорсингу дасть змогу врегулювати відносини між аутсорсинговою компанією та підприємством-замовником, а також удосконалити організаційно-методичні аспекти організації обліку на засадах аутсорсингу.

\section{Висновки}

Підводячи підсумки описаного вище варто зазначити, що бухгалтерський облік не є основним бізнес-процесом для підприємства. Однак саме від правильності організації бухгалтерського обліку залежить уся господарська діяльність підприємства. Внутрішня бухгалтерська служба, окрім цього, що вимагає значних витрат на своє утримання, не завжди якісно здійснює покладені не неї обов'язки. 
У таких умовах делегування ведення бухгалтерського обліку на аутсорсинг дає змогу підприємству сконцентрувати увагу на головній місіі. При цьому бухгалтерський аутсорсинг виступає інструментом оптимізації витрат, забезпечує створення конкурентоспроможних підприємств, сприяє реальному збільшенню їх прибутків завдяки тому, що пришвидшує ведення фінансового та податкового обліку при одночасному поглибленні й розширенні можливостей управлінського обліку.

\section{References}

1. Davydyuk, T. V., \& Lehotska, Yu. I. (2018). Bukhhalterskyy autsorsynh yak innovatsiynyy instrument dosyahnennya ekonomichnykh perevah. Economic journal Odessa polytechnic university, 1(3), 11-18. [In Ukrainian].

2. Kesarchuk, H. S. (2014). Bukhhalterskyy autsorsynh: ponyattya, vydy, perevahy ta nedoliky. Naukovyy visnyk Uzhhorodskoho universytetu. Seriya Ekonomika, 1(42), 201-204. [In Ukrainian].

3. Lyakhovych, H. I. (2016). Bukhhalterskyy aut-sorsynh: pidkhody do traktuvannya ta klasyfikatsiyi. Naukovyy visnyk Uzhhorodsko- ho natsionalnoho universytetu. Seriya Mizhnarodni ekonomichni vidnosyny ta svitove hospodarstvo, 9, 104-108. [In Ukrainian].

4. Lyakhovych, H. I. (2017). Analiz dotsilnosti perekhodu na bukhhalterskyy autsorsynh. Problemy ekonomiky, 42, 392-397. [In Ukrainian].

5. Lyakhovych, H. I. (2017). Komparatyvnyy analiz naukovykh pidkhodiv do otsinky efektyvnosti bukhhalterskoho aut sorsynhu. Naukovyy visnyk Mizhnarodnoho humanitarnoho universytetu. Seriya Ekonomika i menedzhment, 28, 213-219. [In Ukrainian].

6. Nazarenko, O. V., \& Surovytska, A. V. (2018). Autsorsynh bukhhalterskoho obliku: perevahy, nedoliky ta osoblyvosti zaprovadzhennya. Ekonomika ta derzhava, 12, 50-54. [In Ukrainian].

7. Skakun, L. S. (2010). Bukhhalterskyy oblik v umovakh autsorsynhu (summary of the dissertation ... of the candidate of economic sciences). Zhytomyr: Zhytomyr State University of Technology. [In Ukrainian].

8. Volot, O. I., \& Mytko, A. P. (2014). Bukhhalterskyy autsorsynh: sutnist, klasyfikatsiya ta oblik. Formuvannya rynkovykh vidnosyn v Ukrayini, 7, 76-79. [In Ukrainian].

S. M. Pylypenko, N. P. Banera, L. O. Heley

Ivan Franko National University of Lviv, Lviv, Ukraine

\section{CLASSIFICATION OF ACCOUNTING OUTSOURCING AND APPROPRIATENESS OF ITS APPLICATION IN UKRAINE}

The research has revealed that a problem of insufficient development of outsourcing in Ukraine exists, although a significant potential for its development may allow significant increasing of competitiveness of business entities. In course of the research the content of outsourcing services and organizational principles of accounting outsourcing are defined. The conceptual apparatus of accounting outsourcing is identified. The advantages of using the services of outsourcing are given, which allows providing quality accounting services, reducing the cost of maintaining the internal accounting staff, high qualification and competence of the outsourcer as a worker of an outsource company are pointed out. Various types of accounting outsourcing services are defined. The distinguishing features of accounting outsourcing processes, phenomena and characteristics are described, some options for an outsourcing company with enterprise-customer of accounting outsourcing are generalized. The expediency of application of accounting outsourcing in the activities of small and medium enterprises is clarified. The combined accounting of the enterprise by internal accounting staff and outsourced accountants in activities of large enterprises is substantiated. The assessment of economic efficiency is determined as the most effective method of substantiation of expediency of application outsourcing. A formula for quantifying the size and selection forms of organization and accounting is presented as well. The list of quality methods for evaluating the effectiveness of accounting outsourcing is given. The factors that should be taken into account during the search and choice of a thorough and reliable outsourcing company are identified. The influence of factors to be considered when searching for and choosing a conscientious and reliable outsourcer is assessed. Assembly is recommended terms of reference with pre-formed selection criteria. The importance of taking into account when choosing an outsourcing company option in dealing with accounting outsourcing - standard or extended is established; the main provisions, advantages and disadvantages of each are described. The main trends of development of accounting outsourcing in Ukraine and prospects of its development, which are associated with the need to take appropriate legislative and regulatory documents, are outlined.

Keywords: accounting; accounting outsourcing; outsourcer; types of accounting outsourcing; feasibility of implementing of accounting outsourcing. 